inols $\left(\begin{array}{c}1.0 \\ (5)\end{array}\right.$

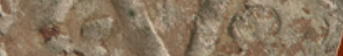

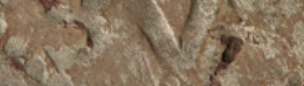

$-1020$ (3.)

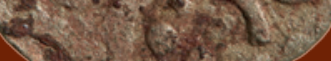

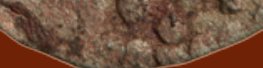
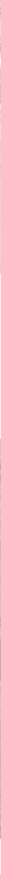

KUML 2017
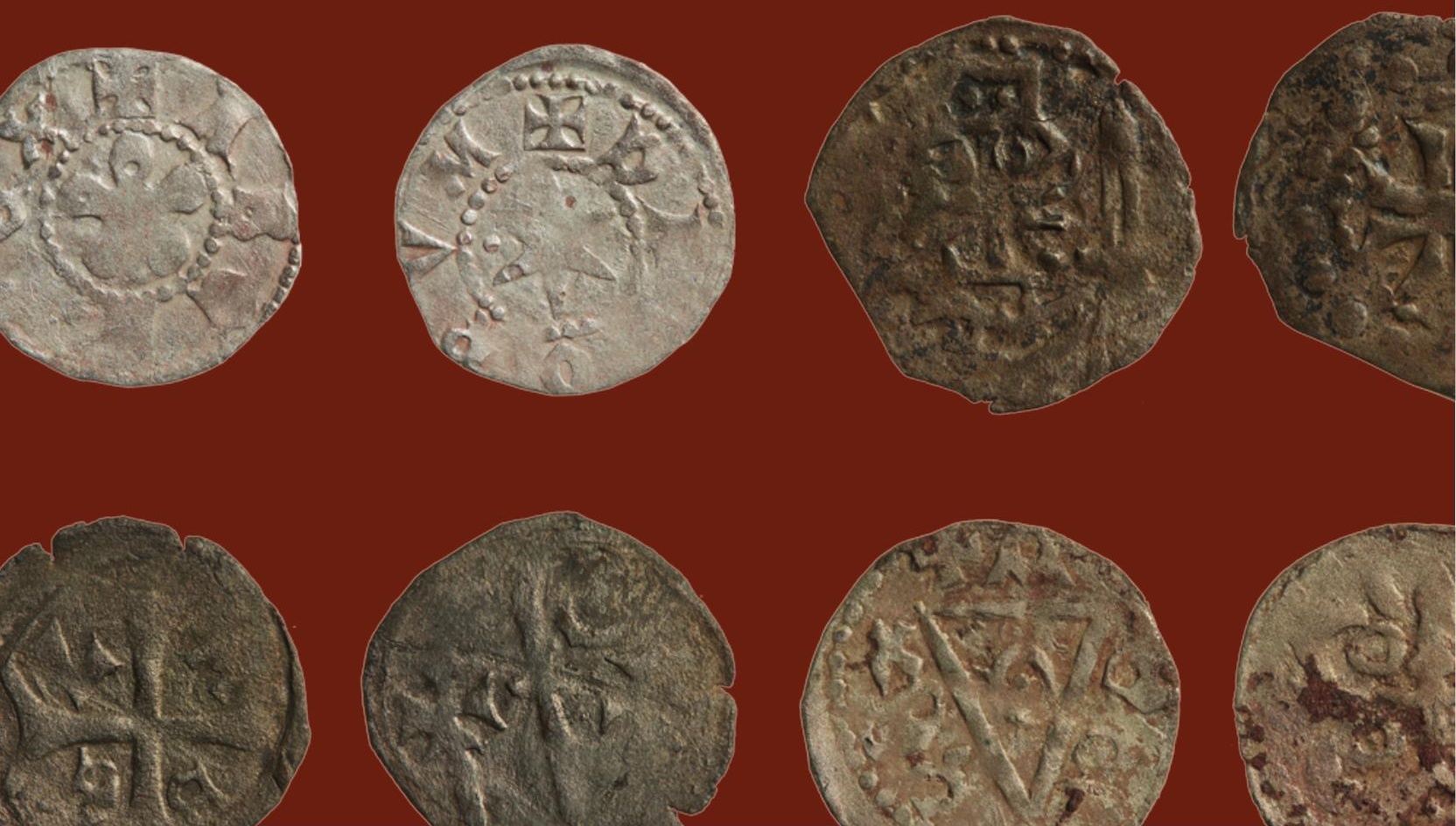


\section{KUML 2017}

Årbog for Jysk Arkæologisk Selskab

With summaries in English

I kommission hos Aarhus Universitetsforlag 


\title{
På jagt efter guldhornenes findested
}

\author{
Af SVEN THORSEN
}

Når man ikke søgte, fandt man noget, og når man søgte, fandt man intet. Johannes Brøndsted 1954

Som det vil være de fleste bekendt, blev de to store guldhorn fundet i Gallehus nord for Møgeltønder. Også at det i 1639 var en ung pige og i 1734 en fattig husmand, der fandt hornene. Men de præcise fundsteder kendte man ikke, hvorfor professor P.V. Glob i 1952 besluttede at undersøge området for - om muligt - at finde spor af noget, der kunne forklare nedlæggelserne. Undersøgelserne blev videreført i 1964, 1969 og 1971-72, men desværre uden at der blev skrevet nogen afsluttende rapport. Da jeg deltog i de sidste udgravninger og dengang opmålte det meste af det undersøgte område, er jeg blevet opfordret til ud fra det foreliggende materiale at sammenfatte resultaterne af de forskellige undersøgelser.

\section{Baggrunden for undersøgelserne}

P.V. Glob havde, da han i 1949 blev leder af Århus Museum, omdøbt det til Forhistorisk Museum og udvidet arbejdsområdet til hele den jyske halvø. Takket være hans gode forhold til Nationalmuseets direktør, Johannes Brøndsted, gav det ikke anledning til de store problemer, og da Glob var godt på vej til at blive en arkæologisk berømthed, var vejen til Gallehus ikke lang.

Tanken om at grave der må være luftet allerede i 1951, hvor Forhistorisk Museum havde vakt opmærksomhed ved at bruge det, man kaldte "krigsinstrumentet minesøgeren" i Illerup Ådal. Det havde, skrev Glob til Johannes Brøndsted, ført til "skriveri i bladene" og "rygter om, at vi vilde fortsætte på samme måde i Gallehus".

Globs brev var svar på et, Brøndsted havde sendt i oktober 1951 for at orientere om, at han fra "en mig ubekendt civilingeniør" havde modtaget et forslag om en undersøgelse "ved Gallehus med den type minesøger, som ogsaa 


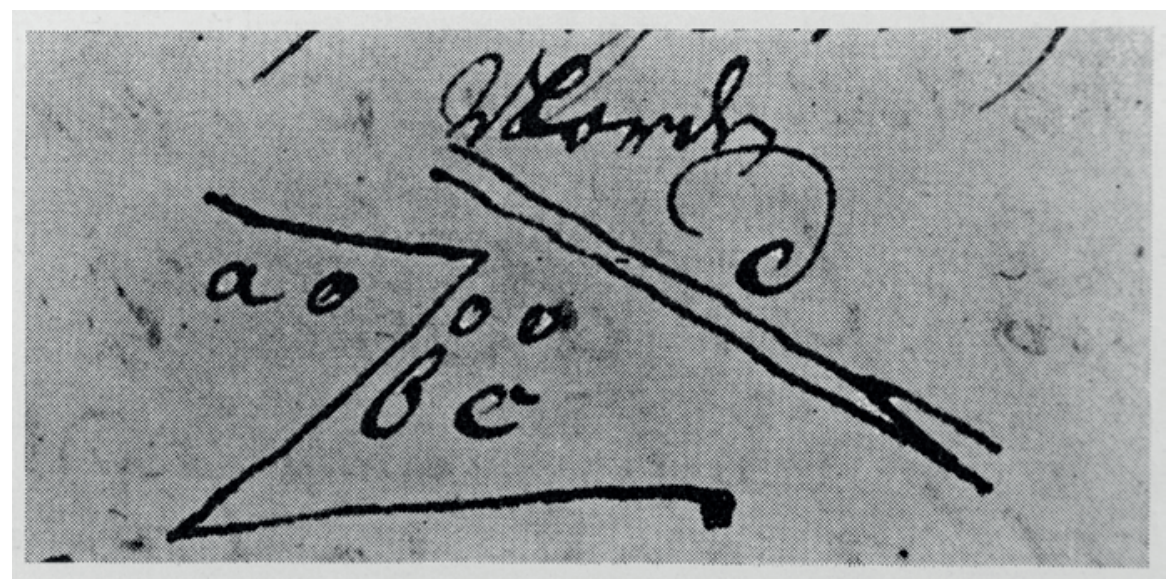

Fig. 1. Grev Schack ledsagede i 1734 sin tegning med følgende beskrivelse af "Galgehuus eller efter den jyske talemåde Gallehuus": "Byen har en lignelse af et 2-tal. a er huset, hvor manden bor, som fandt hornet, b er den gamle kule sydøst for, hvor det forrige horn for 95 år siden er funden, og imellem huset og samme kule er 25 skridt, samme gamle kule kaldes endnu guldkulen og er ungefehr 3 alen i kvadrat og en alen dyb, c er den nye kule sydøst for, hvor dette nye guldhorn er fundet, imellem den og den gamle kule er ungefehr $3 \frac{1}{2}$ skridt, $d$ er landevejen, som går norden fra til Tønder og imellem den nye kule og landevejen er 24 skridt”. - Efter Iversen 1950.

In 1734, Count Schack accompanied his drawing with the following description of Gallehus: "The town resembles the number 2 in form. a is the house where the man who found the horn lives, $\mathrm{b}$ is the old pit where the previous horn was found 95 years ago, and between the house and the pit there are 25 paces, this old pit is still referred to as the gold pit and is about 3 alen square and 1 alen deep, $c$ is the new pit to the southeast, where the new golden horn was found, between this and the old pit there are about $3 \frac{1}{2}$ paces, $d$ is the highway that goes from the north to Tønder and between the new pit and the highway there are 24 paces".

registrerer ikke-magnetiske metaller”. Brøndsted var noget skeptisk med hensyn til "gyldne resultater", men havde alligevel svaret ingeniøren, at Nationalmuseet var interesseret, og til Glob skrev han: "Mulig har De ogsaa tænkt paa en undersøgelse ved Gallehus? Hvis De har lyst, skal De ogsaa være hjertelig velkommen til at være med til sin tid".

Glob var tydeligvis ikke interesseret i blot at være tilskuer og svarede: "Som De ved, har jeg for længe siden planlagt en undersøgelse af området og i den anledning allerede foretaget en del undersøgelser både arkivalt og på selve fundstedet. Ved mit sidste besøg dernede fik jeg nærmest et chok, da man umiddelbart forinden netop havde afgravet et betydeligt stykke af det areal, som burde undersøges, flyttet stenene m.m. med Nationalmuseets tilladelse”. Altså både en markering af Forhistorisk Museums interesse og en kritik af Nationalmuseet, der åbenbart ikke havde modsat sig den udvidelse af vejen, 
der havde gnavet en bid af området. Enden på historien blev, at Brøndsted efter en snak med lederen af Nationalmuseets oldtidsafdeling svarede, at denne "tiltræder ganske, at sagen overgaar til Dem", med tilføjelsen "saadan som vi talte om i sin tid”. Hvad der så måtte ligge i det!

Museumssagen indeholder intet om arkivalske undersøgelser, og sandsynligvis indskrænker disse sig til, at Peter Kr. Iversen, der var arkivar ved Landsarkivet i Aabenraa, i april 1951 havde sendt Glob et særtryk af en artikel i Sønderjysk Månedsskrift med en bemærkning om, at det "måske kan være af interesse ved Deres eftersøgning efter den manglende del af det lille guldhorn". Dette må henvise til, at Glob har udtrykt ønske om at lokalisere fundstedet og eventuelt finde den manglende del af det lille guldhorn, og derfor fandt Iversen altså, at det måtte interessere Glob, at han i Gram godsarkiv havde fundet en længe savnet kopi af den indberetning, som grev Schack umiddelbart efter fundet af det sidste guldhorn havde indsendt til hofmarskallatet. Hvad der var ganske interessant, fordi der i denne var en skitse af begge guldhorns findesteder (fig. 1).

\section{Hvad man på forhånd vidste}

Før Iversens fund af grev Schacks indberetning havde flere forsøgt at udpege findestederne. De mest seriøse forsøg var gjort af oldforskeren C.C. Rafn og historikeren P. Lauridsen i henholdsvis 1855 og $1908 .{ }^{2}$

Ifølge Rafn skulle 1639-guldhornet være fundet på vejstykket mellem de huse, han på en kortskitse har betegnet med a og b, se fig. 2. Dog med det forbehold, at "det er vel ikke afgjort, at Veien nu har ganske samme Beliggenhed som den gang". 1734-guldhornet skulle derimod være fundet i nærheden af det hus, der på kortskitsen er betegnet med et c, men han tilføjer, "dengang fandtes intet Huus paa dette Sted".

P. Lauridsen var mere konkret, hvilket hænger sammen med, at Nationalmuseets direktør, Sophus Müller, på trods af at Gallehus lå syd for den daværende grænse, ønskede, at der "paa en eller anden Maade kunde rejses et stedligt Minde for det mærkværdigste Oldtidsfund, der nogensinde er draget frem af Fædrelandets Jord". ${ }^{3}$ Derfor skulle Lauridsen forsøge at udpege findestederne så præcist, at greven på det nærliggende gods Schackenborg kunne købe arealet og rejse et par mindesten.

Lauridsens udpegninger tog udgangspunkt i huset, som 1734-guldhornets finder, Erik Lassen, boede i. Nemlig det tredje hus i husrækken på vestsiden af den vej, der afgrænsede byens ubebyggede gadeplads. Huset var ganske vist brændt i 1832. Det samme var to nabohuse. Det nordligste blev efterfølgende 


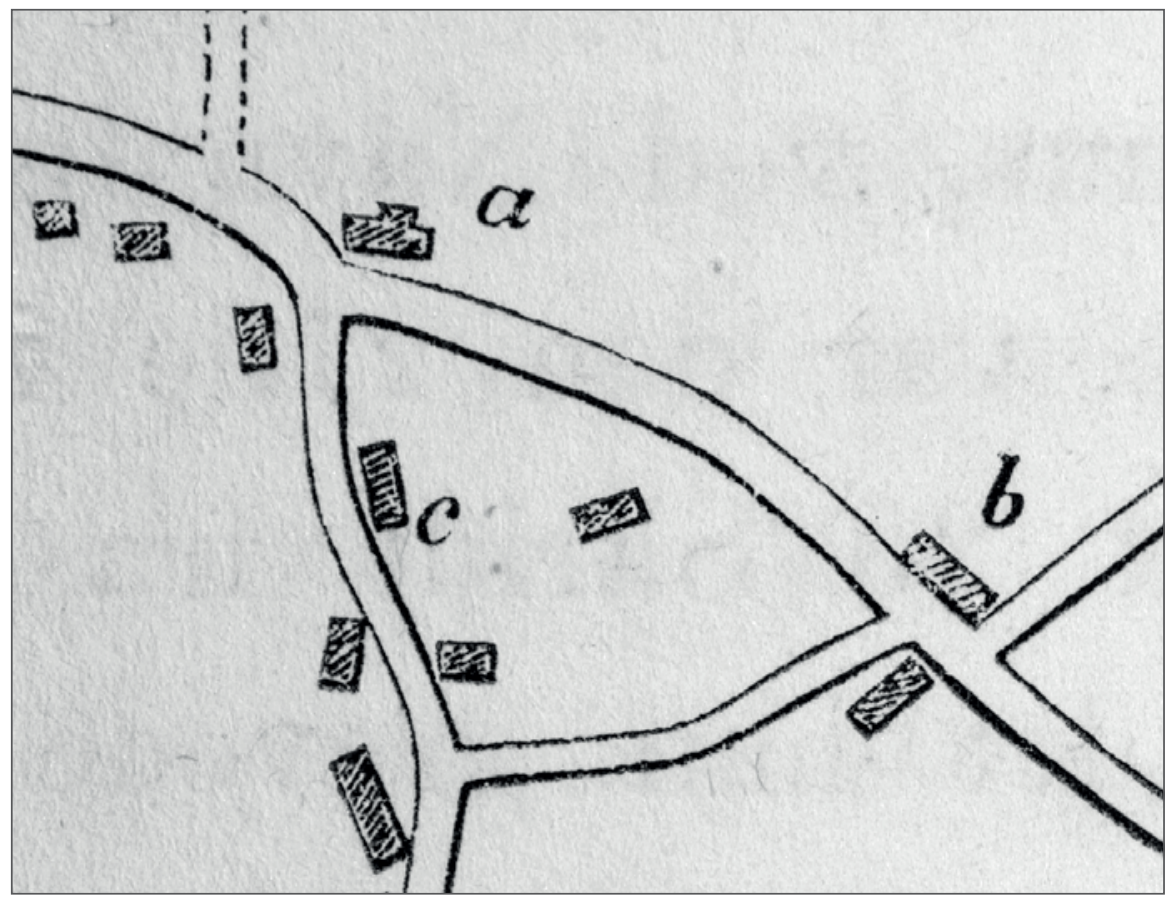

Fig. 2. Rafn ledsagede i 1855 sin artikel med dette kort, der viser bebyggelsen langs vejene omkring byens fælles, trekantede gadeplads. Med lidt god vilje har bebyggelsen langs den østlige og sydlige vej "lignelse af et 2-tal". - Kortudsnit efter Rafn 1855.

Rafn accompanied his 1855 article with this map, which shows the buildings alongside the roads running around the town's triangular village green. With a little imagination, the settlement along the eastern and southern roads can be made to "resemble the number 2 ".

genopført på sin gamle plads, mens det mellemste, som Lauridsen på kortet betegner a, blev flyttet over på den modsatte side af vejen, hvor han kalder det b. (Lidt forvirrende, for på Rafns kort kaldes det c). Erik Lassens hus blev ikke genopbygget, men Lauridsen angiver, at det havde ligget i flugt med husrækkens nordlige huse, og ud fra dette og nogle kendte afstande mente han at kunne fastlægge findestederne for begge guldhorn.

Svaghederne ved Lauridsens udpegninger er, at han ikke vidste, om de oplyste afstande var fra et hushjørne eller fra en dør, og desuden at afstandene var angivet i skridt. Om denne usikkerhed skriver han: "Ved Skridt forstaas paa Egnen fra gammel Tid Dobbelttrin eller Favne, idet der kun tælles for hvert andet Fodslag, og omsat til Nutidsmaal vil det altsaa sige, at Guldhornet 1734 fandtes o. 69 Alen [43 meter] lige Øst for Erik Lassens Hus, og Hornet 1639 o. 75 Alen [47 meter] fra samme Hus i mere nordøstlig Retning”. 


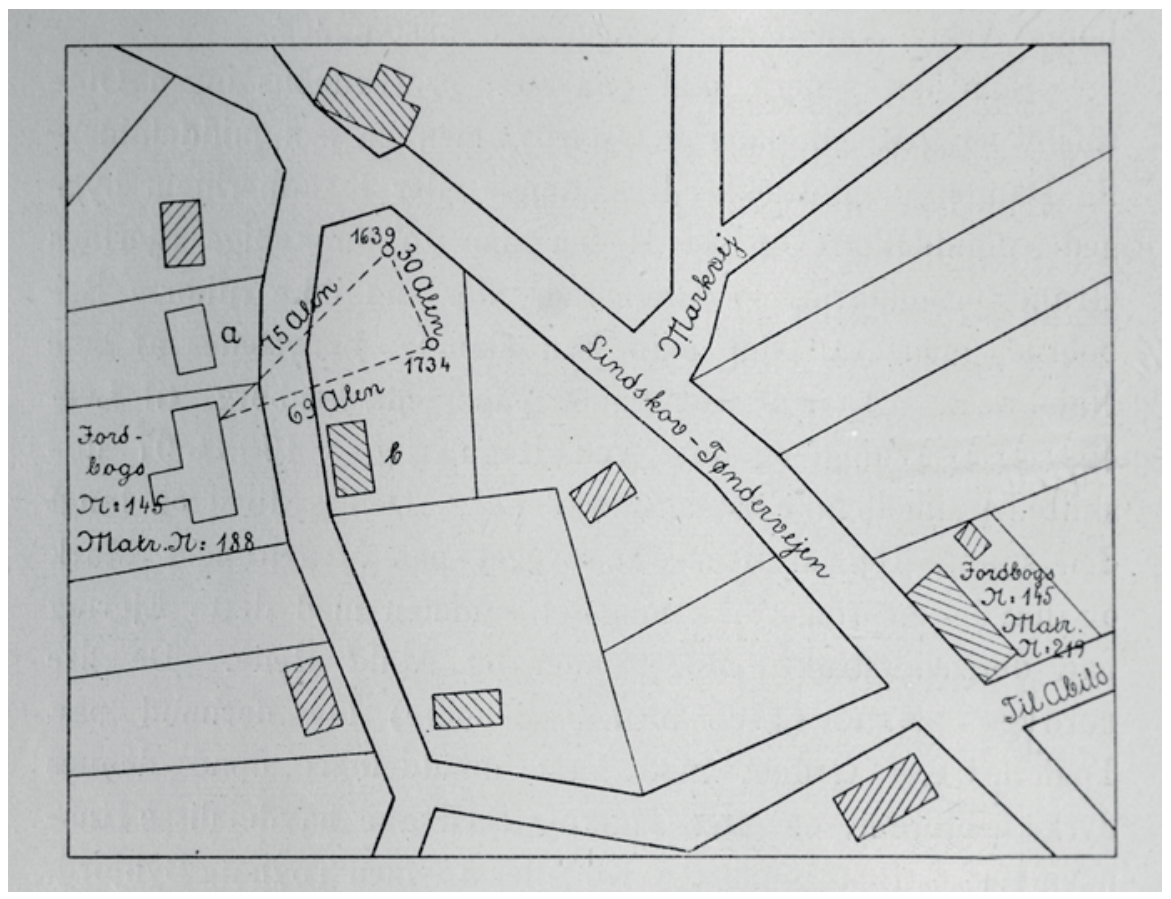

Fig. 3. Sådan konstruerede Lauridsen sig i 1908 frem til de to fundsteder. - Efter Lauridsen 1908.

How Lauridsen worked out the locations of the two find spots in 1908.

Set i forhold af Lauridsens beregninger må grev Schacks nyfundne beretning fra 1734 (fig. 1) dog tillægges større kildemæssig værdi. Af den fremgår det, at det første guldhorn var blevet fundet $47 \mathrm{~m}$ sydøst for Lassens hus, at det andet horn blev fundet ca. $7 \mathrm{~m}$ længere mod sydøst, og desuden at afstanden til landevejen var $45 \mathrm{~m}$, hvorfra den så end måtte være målt. Ikke desto mindre synes Glob dog med de første udgravninger at have taget udgangspunkt $i$ en efterprøvning af Lauridsens angivelser af, hvor guldhornene skulle være fundet, og hvor Lassens hus havde ligget.

\section{Udgravningen i 1952}

Med Globs vågne blik for muligheder var det et rent skattekort, Iversen havde fundet. Det gav ham selvfølgelig lyst til at grave, men uden at bruge minesøger. For i brevet til Brøndsted understreger han, at en rent arkæologisk undersøgelse "selvsagt vil overflødiggøre minesøgerne, der kun ville ødelægge endnu mere, 


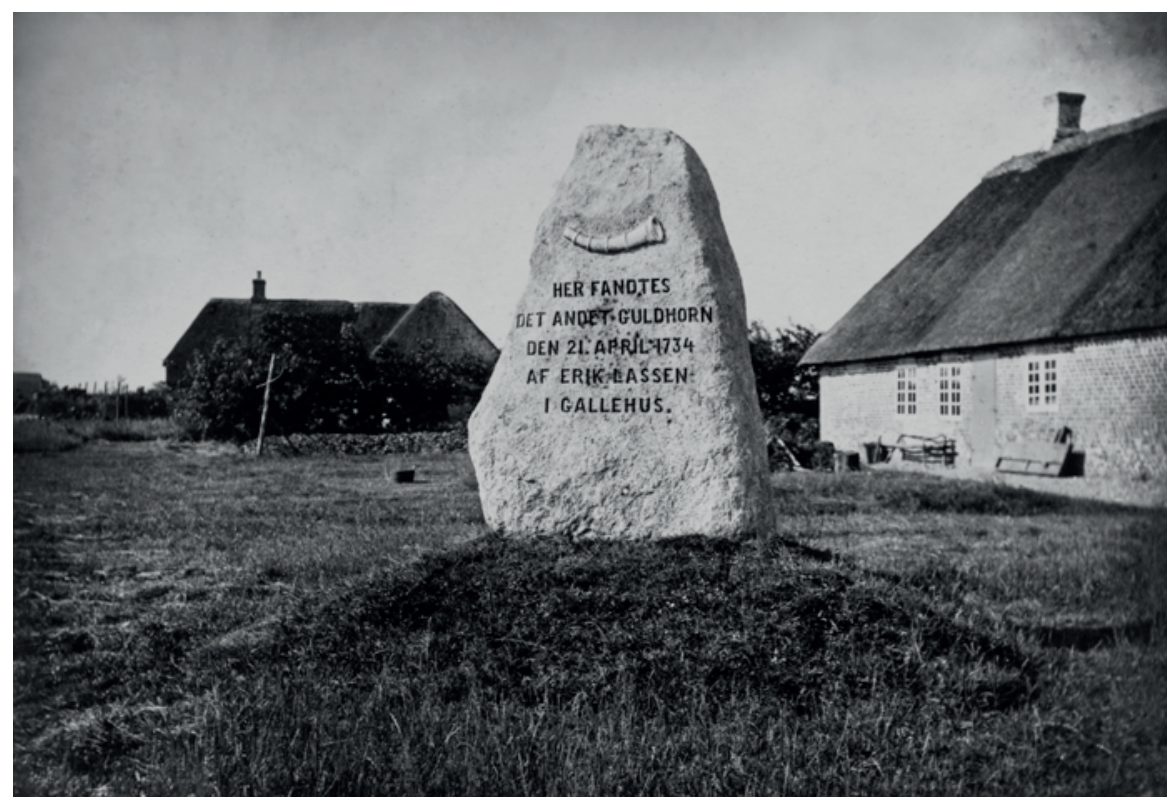

Fig. 4. Som afslutning på Lauridsens undersøgelser købte lensgreve Schack på Schackenborg i 1907 arealet, hvor guldhornene var fundet og lod to mindesten rejse. Det kostede noget besvær, fordi egnen er så stenfattig, at stenene, efter hvad sønnen fortalte, måtte hentes i Harzen. Huset længst til højre er det, der efter en brand i 1832 blev opført på gadepladsen. Eller rettere en erstatning for dette, fordi det atter en gang var brændt. - Efter postkort, Moesgaard Museum.

On conclusion of Lauridsen's investigations in 1907, Count Schack of Schackenborg bought the area where the golden horns were found and had two commemorative stones erected. This was not without its difficulties, because stones are such a rarity in the area that, according to his son, the stones had to be acquired in the Harz. The house on the far right is the building that, following a fire in 1832, was built on the village green. Or more correctly, a replacement for it, because it had burnt down again in the meantime.

hvis man begyndte en undersøgelse med dem”. Bagefter kunne man for hans skyld "prøve minesøgerne, hvor man lyster".

I begyndelsen af april 1952 foretog Glob og museumsinspektør Harald Andersen en rekognoscering i Gallehus, og en efterfølgende henvendelse til Jydske Ingeniørregiment tyder på, at Harald Andersen ikke delte Globs uvilje mod at bruge minesøger. Men det viste sig at være forbundet med visse vanskeligheder, fordi regimentet stod for at skulle hjemsende sine styrker, og de nyindkaldte ville først "være brugelige om et par måneder". Hastede det, ville man dog forsøge at skrabe nogle minesøgere sammen. Glob svarede, at man gerne ville have hjælp i juni. 
Udgravningen begyndte den 4. maj, og hvis hensigten var at vække opmærksomhed, var datoen velvalgt. For det var, bemærker Harald Andersen i udgravningsberetningen, netop på 150-årsdagen for guldhornstyveriet. Brøndsted havde gerne set en senere opstart. Den "unge grev Schack" havde nemlig inviteret både ham og Glob til at bo på Schackenborg, og selv om undersøgelsen med Brøndsteds ord "helt igennem er Deres", ville han gerne "overvære i hvert fald noget af den som velvillig spektator". Men da Brøndsted først havde tid i slutningen af maj, måtte Glob skuffe sin gamle lærer, som på dette tidspunkt må have været i gang med den bog om guldhornene, der kom i 1954.

Af Harald Andersens kortfattede udgravningsberetning fremgår, at udgravningen varede til den 17. maj. I dette tidsrum havde man nået at grave to lange grøfter mellem mindestenene og desuden en del søgegrøfter i det område, hvor Erik Lassens hus havde ligget (fig. 5).

Formålet med grøfterne var angiveligt at fastslå, om mindestenene virkelig stod på findestederne, og man gik så forsigtigt frem, at muldlaget i de udlagte felter på omkring 65 kvadratmeter blev gennemgravet med graveskeer. Det gav en masse fund, "men ikke et eneste, der med sikkerhed kan siges at tilhøre oldtiden", fortæller beretningen, der opregner fundene: "Mønter 4 stk., andre metalgenstande (hestesko, søm, patronhylstre osv.) 269 stk., rudeglas 53 stk., flaskeglas 37 stk., jydepotteskår 49 stk., stentøj 15 stk., porcelæn 117 stk., fajance 11 stk., lertøj 91 stk., og murbrokker 319 stk.”. Fund der forklarer beretningens indledende konklusion: "Jorden på de undersøgte steder var så fuld af metaldele, at enhver tanke om at anvende minesøger her på forhånd opgaves".

Da muldlaget var fjernet sås næsten overalt grågul, let blandet jord, der i første omgang opfattedes som overfladen af den urørte undergrund. Ved nærmere undersøgelse viste det sig imidlertid ikke at være tilfældet. Jorden var næsten overalt gennemgravet med større og mindre huller, der løb sammen og greb ind over hinanden. Fylden i disse gruber bestod overvejende af undergrundsmateriale - deraf det fejlagtige førstehåndsindtryk. Dette kunne jo for så vidt tyde på, at gruberne er fyldt op, ret snart efter at de er gravet. I flere af dem (navnlig de større) sås dog i bunden et mørkt, næsten moseagtigt lag, der taler for, at i hvert fald disse gruber har stået åbne i nogen tid, og at der har stået vand i dem. Gruberne blev ikke totaludgravet. Alle blev dog snittet, og de, der kunne ses i grøfternes nordvægge, blev tegnet. I udgravningsberetningen hedder det " $i$ alle de iagttagne, egentlige gruber lykkedes det at finde daterende genstande (skår, murbrokker). Disse genstande var alle yngre end oldtiden”.

Beretningen savner en egentlig konklusion, når det gæelder spørgsmålet om, hvorvidt mindestenene står på guldhornenes findesteder. Eller rettere om 1734-mindestenen gør det, for på forhånd havde Glob jo konstateret, 


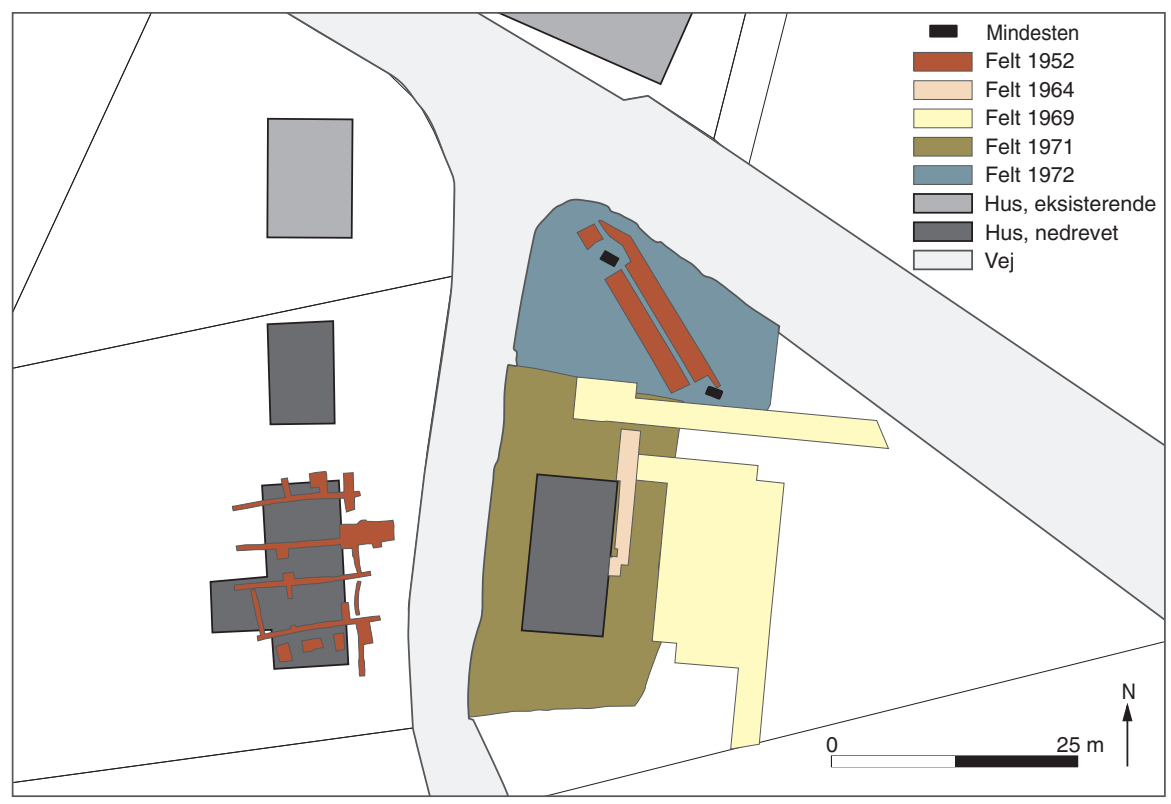

Fig. 5. Udgravningsfelternes placering 1952, 1964, 1969, 1971 og 1972. - Rentegning: Carsten Meinertz Risager, Arkæologisk IT, Moesgaard.

Location of the excavation trenches in 1952, 1964, 1969, 1971 and 1972.

at 1639-stenen i 1949 var blevet flyttet et par meter for at give plads til en vejudvidelse.

Undersøgelsens målsætning om så vidt muligt at bestemme den nøjagtige beliggenhed af Erik Lassens hus lykkedes noget bedre. Dette på trods af, at udgravningerne foregik i en frugthave, hvor det var nødvendigt at lægge søgegrøfterne efter, hvor der var plads til dem. "Hustomten blev fundet. Den viste sig at være særdeles ødelagt, men dog erkendeligt. Kulturlaget, der omgav dens plads, var desværre ikke skarpt afgrænset, så det lader sig ikke gøre (i hvert fald ikke på grundlag af den foreliggende udgravning) at fastslå væggenes nøjagtige plads". Desuden var der problemer med tolkningen af et tilsyneladende dobbelt brandlag, der måtte "underkastes et nærmere eftersyn ved næste udgravning”. For selv om resultatet var magert, var det planen at fortsætte undersøgelserne.

Ifølge en avisomtale skulle de "egentlige udgravninger" foregå i 1953. Men det eneste, der skete, var, at godsforvalteren på Schackenborg i oktober 1954 høfligst erindrede Glob om "den i 1951 fra Schackenborg Godsarkiv udlånte mappe "Guldhornenes findested", der "gerne ønskes returneret". I svarbrevet til godskontoret varslede Glob optimistisk, at han i 1955 igen ville "tage fat med spade og graveske i Gallehus". 


\section{Udgravningen i 1964}

Det var dog først i oktober 1964, der igen blev gravet. Denne gang ikke af Glob, som i 1960 var blevet rigsantikvar, men af arkæologen Olfert Voss. Fra denne udgravning kendes blot en opmåling, der viser en knapt 2 meter bred grøft langs østsiden af det hus, Rafn på sin plan kaldte c og i hvis nærhed, 1734-guldhornet skulle være fundet (fig. 5). På opmålingen ses forskellige rørføringer, og undersøgelsen er sikkert foranlediget af, at huset skulle kloakeres. En detailtegning viser, at Voss har undersøgt et par små fyldskifter i bunden af grøften.

\section{Udgravningen i 1969}

Som rigsantikvar var Glob optaget af at skaffe midler til nye og mere retvisende rekonstruktioner af guldhornene. De skulle være snoede og i rent guld og helst udstilles i Gallehus. Så da der igen blev gravet, var han opsat på at finde ud af, hvor mange mennesker der egentlig besøgte stedet. Af den grund blev der ved denne og senere udgravninger talt busser og biler. Takket være disse tællinger kan man se, at 1969-udgravningen foregik i tidsrummet 4.-18. juni, og at 74 turistbusser og 97 privatbiler gjorde holdt ved mindestenene i løbet af de 12 dage, der blev gravet.

Anledningen til gravningen var, at Glob havde opgivet sin oprindelige plan om at udstille de nye guldhorn i det hus, der efter branden i 1832 var bygget på arealet med fundstederne. Huset havde han ellers fået greven på Schackenborg, Hans Schack, til at købe. Men efter nogle år i forfald var huset blevet en belastning for både Glob og greven. Så idéen var, at en ny gravning skulle puste liv i en ny plan, og kom man på sporet af et af fundstederne, var der desuden nyt at fortælle.

Udgravningen foregik nord og øst for huset (fig. 5), som Olfert Voss havde gravet ved i 1964, og som hjælpere havde Glob lånt to meget rutinerede udgravere af Olfert Voss, nemlig brødrene Johannes og Tage Bruun der i årevis havde stået for den praktiske del af udgravningerne på jernalderbopladsen i Drengsted ved Ribe. Desuden deltog Susanne Andersen, der var arkæologistuderende og stod for opmåling og tegning.

Johannes Bruun, som kendte forholdene i Gallehus fra udgravningen i 1964, mente, at det mest hensigtsmæssige var at gøre som i Drengsted, nemlig at fjerne muldlaget ved hjælp af en traktor med dozerblad. Oversigtsplanen viser fem sådanne afrømmede baner hver på $2 \frac{1}{2}$ meter. De tre parallelt med husets østside og to parallelt med husets nordgavl, i alt 370 kvadratmeter.

Desværre er udgravningen, der måske er den vigtigste, den dårligst dokumenterede. Oversigtsplanen viser kun tomme udgravningsfelter, og de to 


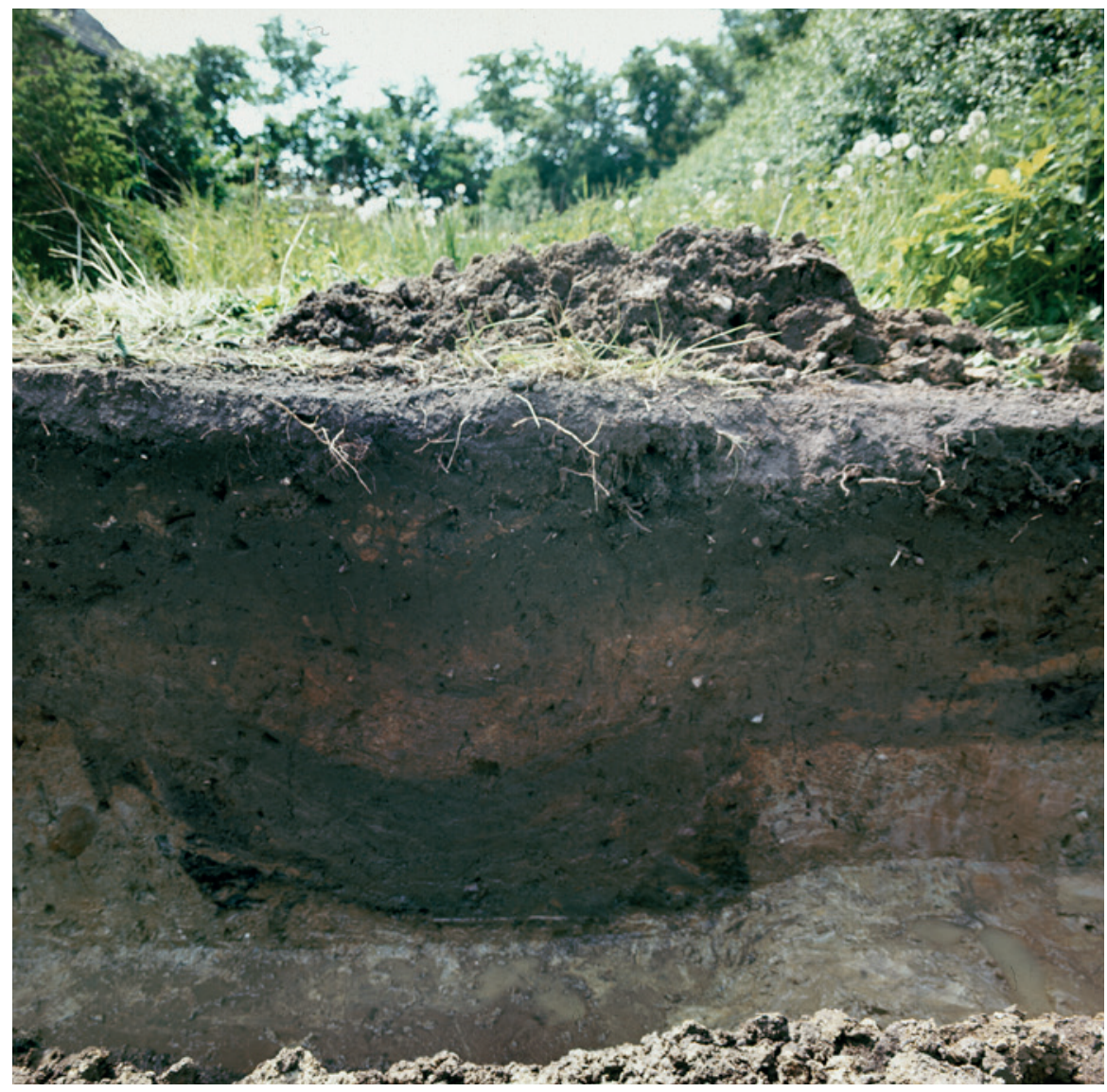

Fig. 6. Det var denne "lergrube", der fik Glob til at tro, at han var på sporet af 1734-guldhornets findested, da han (i grubens venstre kant) mente at se spor efter en sekundær "indgravning". Han beskrev lergruben således: "Muldfyldt og lagdelt. Spredte røde murstensbrokker kun i det øverste lag. Ellers vekslende grå og gule lerede lag til bunden. Enkelte flintbrokker. Ved $8 \mathrm{~m}$ nedskridning af rene lerlag, som var der foretaget mindre indgravninger [efter det manglende stykke af guldhornet fra 1734?]. Bunden af gruben og siderne lige afskåret som i en regulær lergrube". - Moesgaard Museum.

Pit in section trench north of house from 1832. It was this "clay pit" that led Glob to believe that he was on the track of the find spot for the 1734 golden horn, when he (in the left side of the pit) thought he could see traces of a secondary "cut". He described the clay pit as follows: "Stratified soil fill. Scattered red brick rubble only in the upper layer. Otherwise alternating grey and yellow clay-rich layers to the base. Occasional flint rubble. At $8 \mathrm{~m}$ slippage of pure clay layer as if a minor cut had been undertaken [in search of the missing piece of the golden horn from 1734?]. Base and sides of the pit cut off straight as in true clay pit." 
profilopmålinger er dårligt fikserede. Men til alt held er der fra netop 1969-udgravingen bevaret 32 dias. Mest interessant er dog en løs skitse af ni fyldskifter i området mellem 1832-huset og skellet mod øst. Glob har betegnet skitsen "Fot.", og det viste sig, at hele 14 af de 32 billeder, han tog på udgravningen, er af disse fyldskifter, hvilket tyder på, at han må have fundet disse særligt betydningsfulde. Sikkert fordi han mente, at det var gamle lergrave, og at afstanden til Erik Lassens hus var den rigtige.

De bevarede dias gav også nøglen til at forstå forventningerne til de ni fyldskifter. For med disse dias var det muligt at fiksere den ene af profiltegningerne til området umiddelbart nord for de ni fyldskifter, og netop her mente Glob at have fundet et andet lovende spor. Nemlig nogle "mindre indgravninger" i kanten af en "regulær lergrube" (se fig. 6), og som et indskud i beskrivelsen af profilen har han noteret spørgsmålet: "Efter den manglende hornende i 1734?". Dette må betyde, at han 14. juni, da han beskrev profilen, mente at være på sporet af den eftergravning, der blev iværksat lige efter fundet af 1734-guldhornet med det formål i det mindste at finde det manglende stykke af guldhornet. Det samme må være tilfældet, da han få dage senere tegnede skitsen af de ni fyldskifter, for her er tre betegnet "gl" og fem "ny", mens den sidste er betegnet "ny+gammel". Altså også her en nyere nedgravning i en ældre. Skitsen er dateret 17. juni, der var udgravningens næstsidste dag, hvad der nok forklarer, at der ikke var tid til en ordentlig opmåling, for næste dag skulle de ni fyldskifter tømmes. Men herom senere.

\section{Udgravningerne i 1971-72}

I begyndelsen af juli 1971 og i tidsrummet 4.-21. september 1972 gennemførte Glob to store fladeafdækninger i den resterende del af det trekantede areal, der tilhørte Schackenborg (fig. 5). Glob ledede selv udgravningen og kom dagligt på pladsen. Ofte sammen med greve Hans Schack, som han boede hos. Denne artikels forfatter var den gang ansat som tekniker i Rigsantikvarens Fortidsmindeforvaltning og deltog som tegner og udgravningsassistent. Så det var mig, der skulle sørge for opmålinger og i Globs fravær vejlede de to arbejdsmænd og skiftende lokale medhjælpere.

I 1971 blev overjorden i den sydvestlige del af området (ca. 34 x 18 meter) trukket østpå med et dozerblad og placeret i det område, der var undersøgt i 1969 (fig. 7). Derefter blev fladen renskovlet og de fremkomne fyldskifter opmålt. Af den tegnede plan fremgår, at der i udgravningens centrale del blev fundet to sæt let forskudte fundamenter efter det hus, der efter branden i 1832 var genopbygget på denne side af vejen. Siden var huset efter endnu en brand 


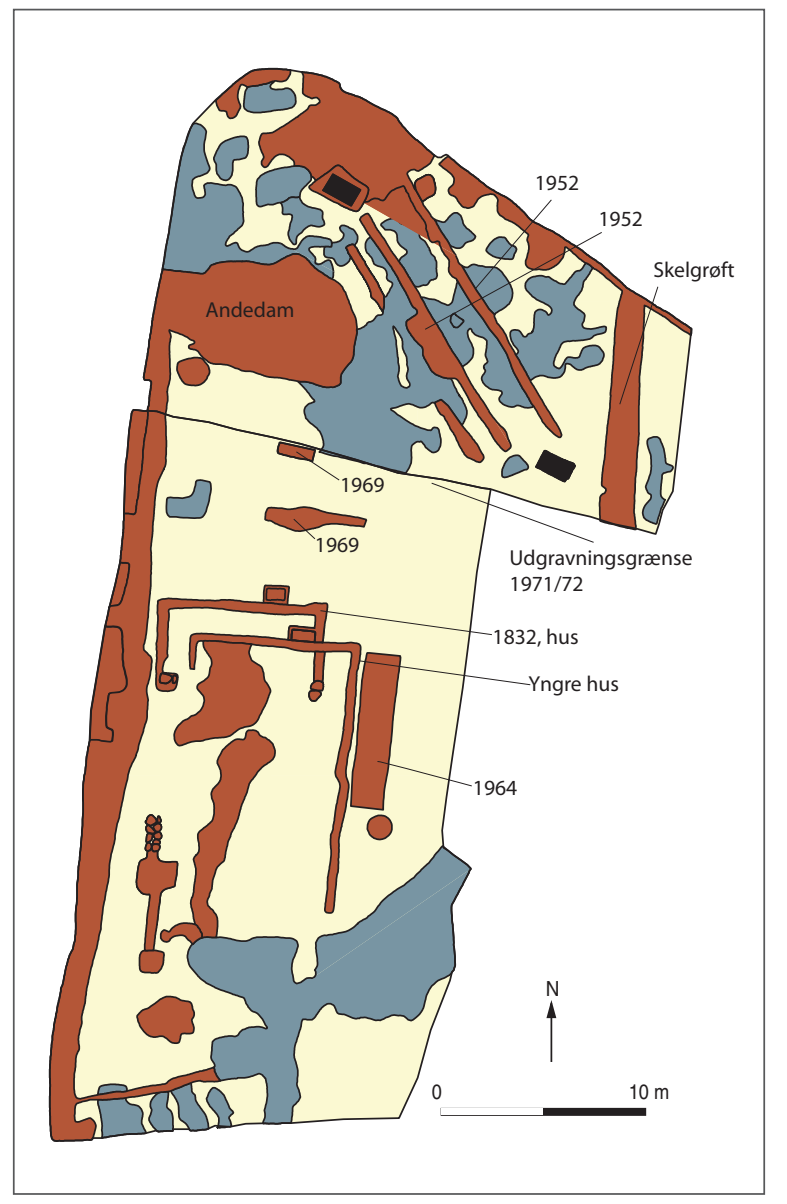

Fig. 7. Sammentegning af udgravningsplanerne fra 1971 (sydlige del) og fra 1972 (nordlige del). For overskuelighedens skyld er der, så godt som det nu lader sig gøre, forsøgt at skelne mellem nyere anlæg/tidligere udgravninger (rød) og gamle lergrave (blå). - Opmåling: Sven Thorsen. Rentegning: Carsten Meinertz Risager, Arkæologisk IT, Moesgaard.

Composite overview, combining the excavation plans from 1971 (southern part) and 1972 (northern part). For greater clarity, a distinction has been made, as far as possible, between more recent features (red) and old clay pits (blue).

blevet genopført, hvad der forklarer dobbeltfundamentet, og så var det blevet revet ned få år før udgravningen i 1971 (se fig. 4).

Vest for huset tegnede vejgrøften sig som et langt sammenhængende fyldskifte, der vest for hustomterne var overlejret af et broklag med stumper af røde teglsten og mod nord af et brandlag, måske fra branden i 1832.

På østsiden af den yngste hustomt fandt vi den grøft, Olfert Voss havde gravet i 1964, ligesom vi nord for huset fandt to lange, Ø-V-gående grøfter fra 1969-udgravningen. Bortset fra sporene efter de tidligere udgravninger var undergrunden nord for hustomterne uforstyrret.

Syd for huset fandtes derimod et omfattende og sammenhængende kompleks på ca. 5x12 meter med gamle lergrave, der var gravet omkring en meter ned i undergrunden (fig. 8). Disse nedgravninger var af samme karakter som 
de ni ikke indmålte fyldskifter, der i 1969 blev fundet øst for 1832-husets nordlige del, og det er derfor nærliggende at betragte 1969-nedgravningerne som sammenhængende med de tilsvarende fra 1971. Er dette tilfældet, er det værd at bemærke, at den sydvestligste del af dette kompleks af lergrave gik ind under sydenden af 1832-huset, hvilket betyder, at i hvert fald den sydligste del af lergravsområdet var i brug før 1832 og sagtens kan være betydelig ældre. Alene udstrækningen tyder på, at det må have været i brug gennem en længere årrække.

Efter opmåling blev de gamle lergrave tømt ved lagvis afskovling. Dog blev der i den del, der lå under 1832-husets sydlige gavl, lagt en tværprofil, der viste, at lergraven en overgang må have stået åben, for 35 centimeter over bunden sås et 5 centimeter tykt lag af fint, fedtet ler, der tydeligvis var vandaflejret. Efter tømningen blev lergravenes sider afrenset og undersøgt for eventuelle

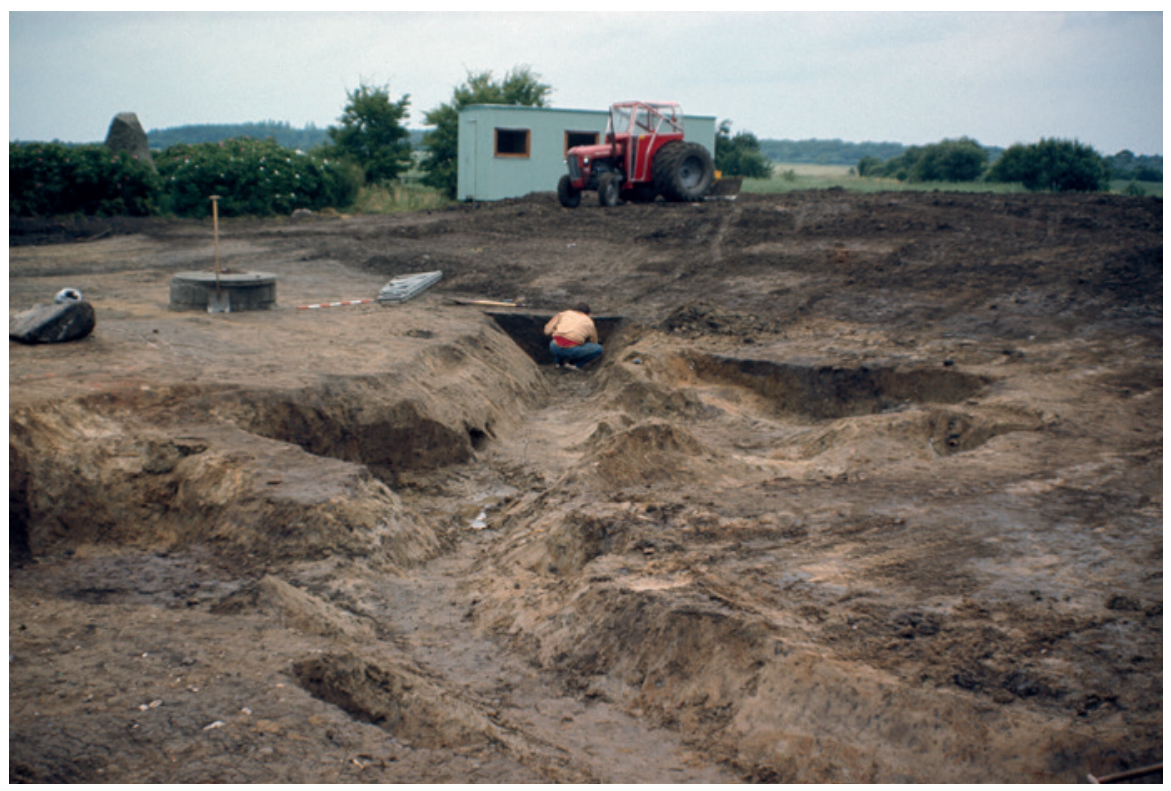

Fig. 8. 1971-undersøgelsens væsentligste resultat var påvisningen af, at der fra sydøsthjørnet af 1832-huset og nordpå fandtes et sammenhængende kompleks af lergrave, der efter alt at dømme også hørte sammen med de lergrave, hvor Glob i 1969 mente at have påvist 1734-guldhornets findested. Billedet viser den del, der blev tømt i 1971. De lergrave, der blev undersøgt i 1969, lå i området mellem manden og traktoren. - Foto: Sven Thorsen.

The most significant outcome of the 1971 investigation was the demonstration that, extending northwards from the southeast corner of the 1932 house, there was a coherent complex of clay pits, which, by all accounts, also encompassed those that Glob had "marked out" as the find spot for the 1734 golden horn. The picture here shows the part that was emptied in 1971. The clay pits investigated in 1969 lay in the area between the man and the tractor. 
anlægsspor. Det førte til fund af trækul i en stensamling i den østlige kant, men da der mellem stenene også fandtes teglstumper, kunne det udelukkes, at det var et anlæg fra oldtiden.

I "guldhornsparcellens" nordligste del, hvor mindestenene står, blev der i 1972 foretaget en afrømning af overjorden på samme måde, som det året før var sket længere mod syd. Det afdækkede område var 27 meter bredt i østvestlig retning og 10-18 meter i nord-sydlig retning. I vest var afgrænsningen igen vejgrøften samt en kloakledning. Mod nord ligeledes vejgrøften og i øst en bred skelgrøft.

I området mellem mindestenene genfandtes 1952-gravningens lange søgegrøfter, og det sås, at disse gennemskar et mere eller mindre sammenhængende kompleks af relativt dybe lergrave, der takket være Harald Andersens profiltegninger er veldokumenterede.

Nord for 1639-mindestenen havde flytningen af stenen i 1949 forstyrret jordlagene. Lidt sydligere fandtes en anden og nyere nedgravning, der på planen er betegnet "andedam", fordi denne ca. 6x9 meter store og 2 meter dybe nedgravning blev tolket som et tidligere gadekær. Dette og hovedparten af de gamle lergrave blev delvist udgravet og bundkoter noteret.

På marken nord for "kroen" (huset der på Rafns tegning (fig. 2) er betegnet med et a) blev der desuden foretaget en mindre prøveudgravning. Årsagen hertil fremgår af sagens papirer, for heriblandt findes et matrikelkort, hvor Glob har sat et kryds og noteret nogle målangivelser og "F[und] iht. 1795". Dette må referere til, at Rafn i 1855 omtaler, at der for "ca. tres år siden”, nord for kroen blev fundet et stykke massivt guld "af Størrelse og Form omtrent som en krumbøjet Finger paa en voxen Mand". ${ }^{4}$ Denne lille prøveudgravning må ses som et vidnesbyrd om, at intet skulle lades uprøvet.

\section{Fundene}

Undersøgelsen af de mange nedgravninger foregik ved at tømme disse med skovl og med opmærksomheden rettet mod daterende fund. For de ældres vedkommende var det overvejende keramik i form af glas, lertøj og fajance, mens det for de yngste var regulært affald af den slags, man førhen smed i nærmeste mergelgrav i håb om aldrig at se det igen. Det uinteressante affald blev straks kasseret, mens ældre, daterbare genstande blev indsamlet og sendt til museet i Tønder.

Guld fandt vi desværre ikke, selv om flere gjorde deres bedste. Både Hans Schack og Glob havde bekendte, der var guldsøgere og fik lov til at forsøge sig i de hel- og halvtømte lergrave. Det mest seriøse forsøg blev gjort af en mand, 


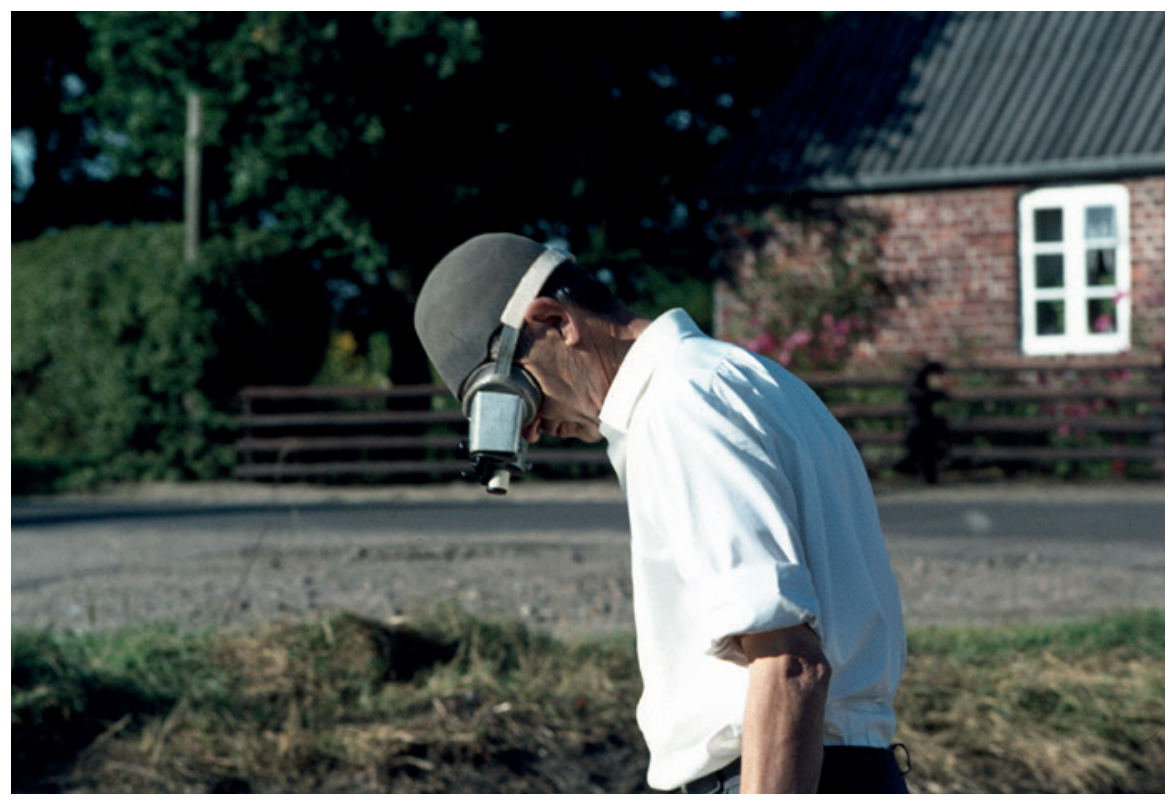

Fig. 9. Guldsøgeren med sin jordkikkert. - Foto: Sven Thorsen.

The gold hunter with his earth telescope.

der havde forbindelse til kasernen i Tønder, og som derfor kunne stille med en minesøger af betragtelig størrelse. Til de mindre seriøse hørte en nobel, ældre jysk redaktør, der fuldt og fast troede på en opfinder-ven, som havde konstrueret en avanceret jordkikkert, der, hvis der var guld i jorden, ville påvirke hans synsnerve (fig. 9). Alle var tavse, men skeptiske tilskuere så, at der ikke skete noget som helst. Dette på trods af, at greven senere afslørede, at han inden eftersøgningen havde gemt en af sine adelige aners velvoksne snustobaksdåser af guld under lidt løs jord.

\section{Hvad ved vi så om guldhornenes findested?}

Ifølge P. Lauridsen blev begge guldhorn fundet i nordenden af byens ubebyggede "gadeplads", der "langt ind i det 19de Aarhundrede henlaa som en Ødemark, gennemhullet af lergrave. Nu er den dyrket og gennemskaaret af Skelgrøfter paa Egnens vis, samt delvist bebygget" ${ }^{5}$ Dette blev grundigt bekræftet ved udgravningerne, for det meste af området var faktisk "gennemhullet" af nedgravninger, hvoraf de fleste må være opfyldte lergrave. Desuden viste undersøgelsen, at "1832-huset" måtte være brændt og erstattet af det, der blev fjernet omkring 1970. Endelig blev der øst for dette hus fundet en opfyldt skelgrøft. 


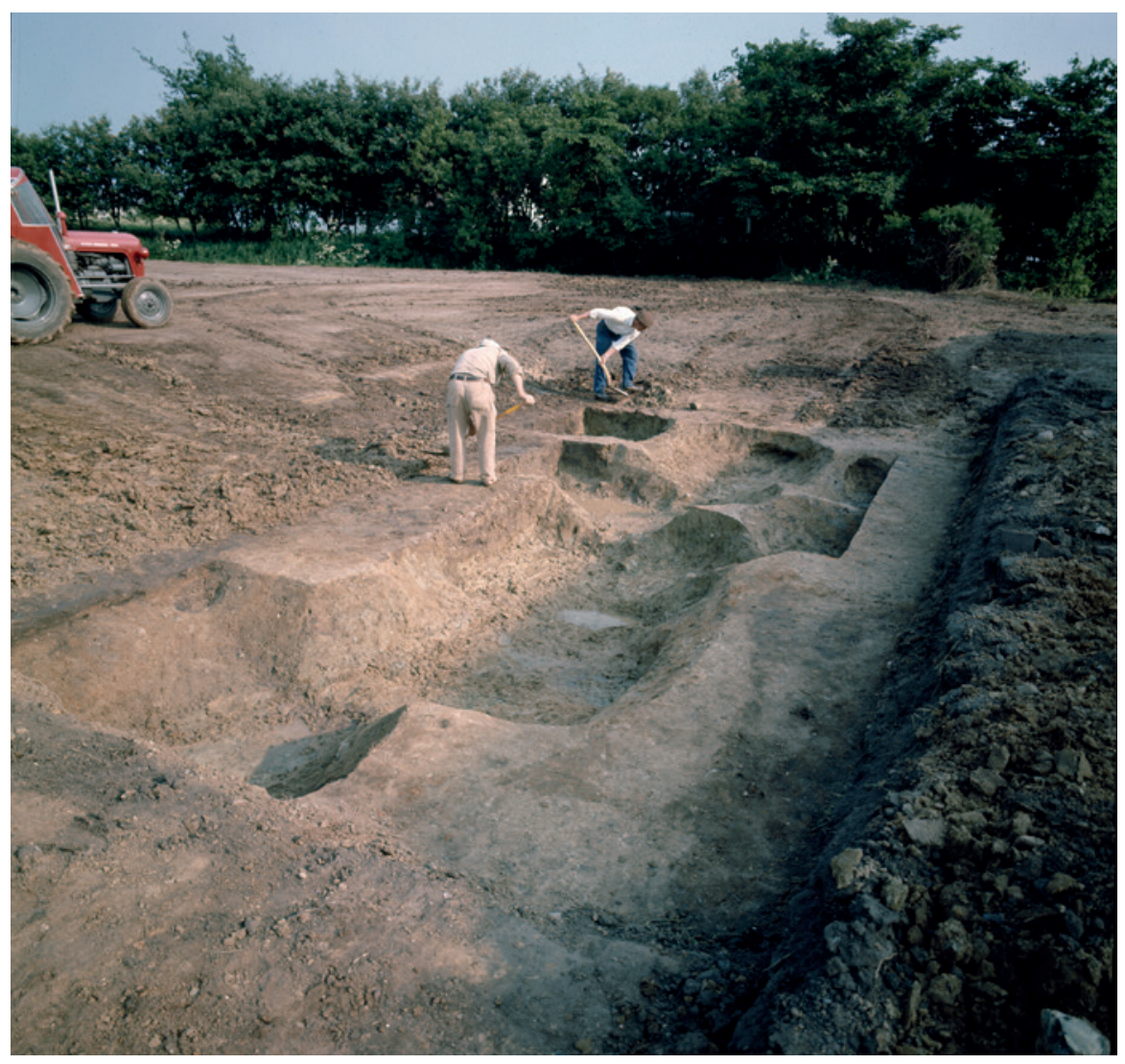

Fig. 10. De ni fyldskifter, lidt øst for 1832-huset, var vel det nærmeste, Glob mente at være kommet 1734-guldhornets findested. Her er de gamle lergrave, som de fremtrådte efter tømningen på 1969-udgravningens sidste dag. - Foto: P.V. Glob 17. og 18. juni 1969.

The nine features located to the east of the house from 1832 were probably the closest Glob believed to have come to the find spot for the 1734 golden horn. Here are the old clay pits as they appeared after they were emptied on the last day of the 1969 excavation.

Ved afslutningen af udgravningen i 1969 kunne Glob fortælle Vestkystens journalist, at mindestenene "er forkert placeret. Men stedet, hvor hornene blev fundet, har vi nu afmærket". ${ }^{6}$ Dette må betyde, at han har ment at have fundet den rigtige lergrav, og her må han have tænkt på de ni fyldskifter, han fandt på gravningens næstsidste dag, og som blev tømt dagen efter (fig. 10). Faktisk samme dag som han må have talt med journalisten og altså på en dag præget af det hastværk, der gerne kendetegner sidstedagen på en udgravning. Dette betød desværre, at fyldskifterne ikke blev ordentligt opmålt, og - hvad værre var - der blev ikke tid til at undersøge, om der kunne findes spor af den 
eftersøgning, grev Schack iværksatte i 1734. Dette ville ellers have været oplagt, når Glob tre dage før mente at have fundet sådanne spor i profilgrøften lige nord for de ni fyldskifter. På den anden side ville det næppe være let at finde sådanne spor. For ifølge Schacks godsinspektør "blev jorden af sex karle paa og omkring stedet en gandske dag om- og opgravet". Spørgsmålet er imidlertid, om de seks karle ville sætte sig erkendbare spor. For hvis formuleringen: "om- og opgravet" skal tages bogstaveligt, må "omgravet" vel betyde, at karlene blot har gennemgravet og eventuelt "opgravet" den løse og sekundære fyld i de gamle lergrave.

Vi må herefter konkludere, at det ikke lykkedes for Glob at påvise og dokumentere guldhornenes nøjagtige findested. I bagklogskabens lys kan man undre sig over, at han langt hen ad vejen valgte at tage udgangspunkt i Lauridsens oplysninger istedet for grev Schacks indberetning fra 1734, hvoraf det fremgår, at det første guldhorn blev fundet $47 \mathrm{~m}$ sydøst for Lassens hus og det andet ca. $7 \mathrm{~m}$ sydøst herfor. Dette område befinder sig ret beset uden for de af Glob åbnede udgravningsfelter (fig. 12).

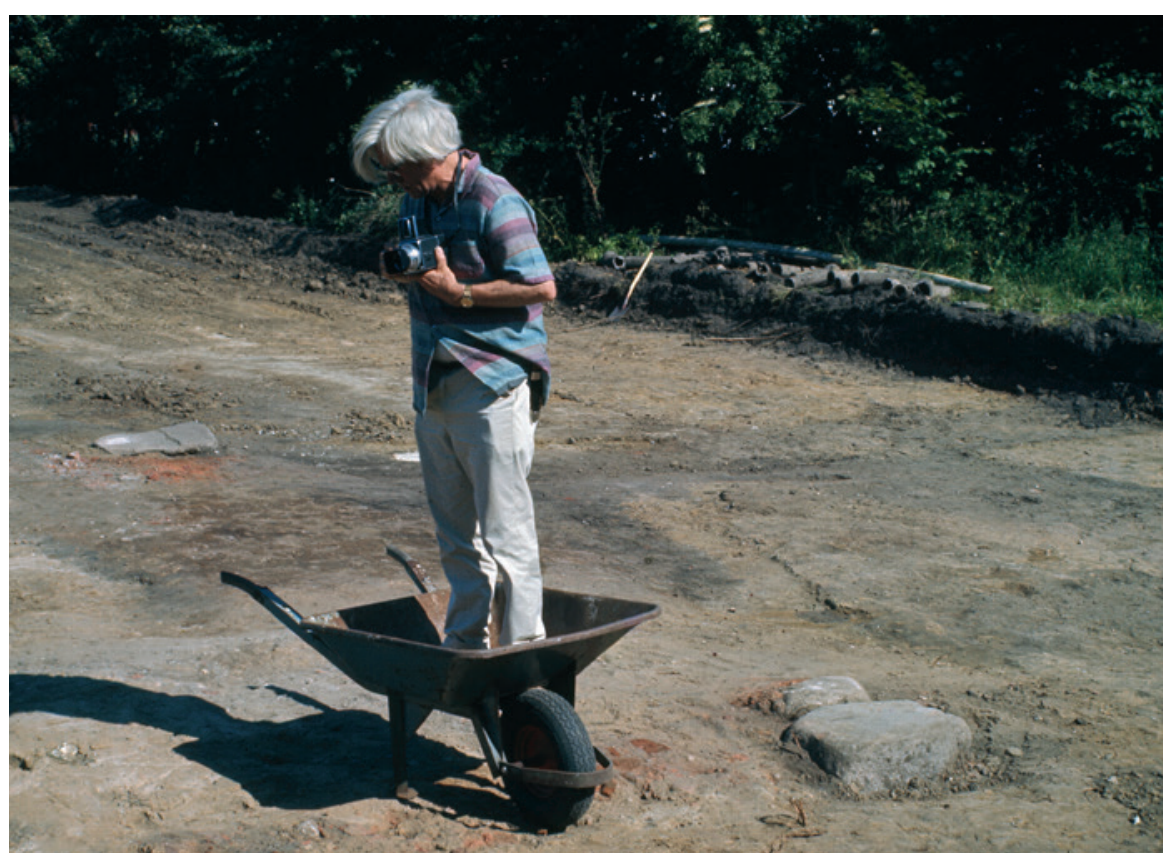

Fig. 11. P.V. Glob på udgravningen 1972. - Foto: Sven Thorsen.

P.V. Glob at the excavation in 1972. 


\section{Var det så alt?}

Det var ikke altid nemt at følge Globs tankegang, men selv om det kunne være svært at se, hvor han ville hen, var der næsten altid en retning. Også når det gjaldt guldhornene. Han var selvfølgelig bevidst om den prestige, der ville være forbundet med at løse blot en enkelt af gåderne omkring landets mest berømte oldtidsfund. Men i lige så høj grad var han drevet af ønsket om at dele sin næsten Oehlenschlägerske betagelse af fundet med andre. Men hvorfor denne vedholdenhed, når resultaterne var så små?

Fra Glob selv foreligger der intet skriftligt om undersøgelserne i Gallehus, og i museumssagen er der ikke engang et avisudklip. Men at aviserne har fulgt udgravningerne er sikkert, og da Nationalmuseet gemmer avisudklip, var det nærliggende at søge her. I den anselige stak af Globs efterladte "guldhornspapirer" var der ikke meget om udgravningerne, men mange udklip om genskabelsen af to nye, snoede guldhorn og om museumsplanerne i Gallehus. I det topografiske arkiv var der til gengæld en stak avisudklip fra 1952, hvor Glob og Harald Andersen fortalte om deres forventninger: "Man kan jo gå med et stille håb om at finde den del, der manglede på det sidste guldhorn, men vi vil dog være yderst tilfredse, om vi blot kan komme så vidt at fastslå, at der en gang har stået et gudehov her. Ifald der har været et sådant, har det ud fra al erfaring at dømme, stået på pæle og hullerne efter disse vil være at finde i lerlaget, såfremt der ikke er gravet alt for voldsomt rundt her i tidligere tid" ${ }^{8}$ Fjorten dage senere måtte Glob imidlertid erkende, at "noget håndgribeligt resultat kom der ikke ud af udgravningen”. Dog var der "opnået andre resultater, som vil blive af betydning, når arbejdet med udgravningerne på pladsen genoptages næste år”. 9

At der så skulle gå 12 år, før der igen blev gravet, betød ikke, at Glob havde mistet interessen for stedet. Omkring 1963 fik han Hans Schack til at købe 1832-huset med henblik på at indrette det til museum. Men skønt den nedsatte styregruppe fik en arkitekt til at udarbejde et projekt, gik tingene i stå. Efter en periode med forfald var huset blevet en belastning for greven, som blev træt af at bortforklare forfaldet med, at der snart ville ske noget. Det var formentlig dette pres, der i 1969 forte til beslutningen om at genoptage udgravningerne og til at nedrive huset. Samtidig arbejdede Glob for, at kulturministeren skulle købe både grevens areal og naboarealet. Her lå et hønseri med et relativt nybygget hønsehus, der kunne indrettes til museum, hvor "et magisk højdepunkt" ville være "en rekonstruktion af de tvende horn i guld af samme lødigheder som de rigtige". ${ }^{10}$ Glob kæmpede hårdt for at rejse den halve million kroner til projektet, men måtte erkende, at tanken om at udstille guldhornene i et hønsehus ikke fandt den fornødne opbakning. Det 


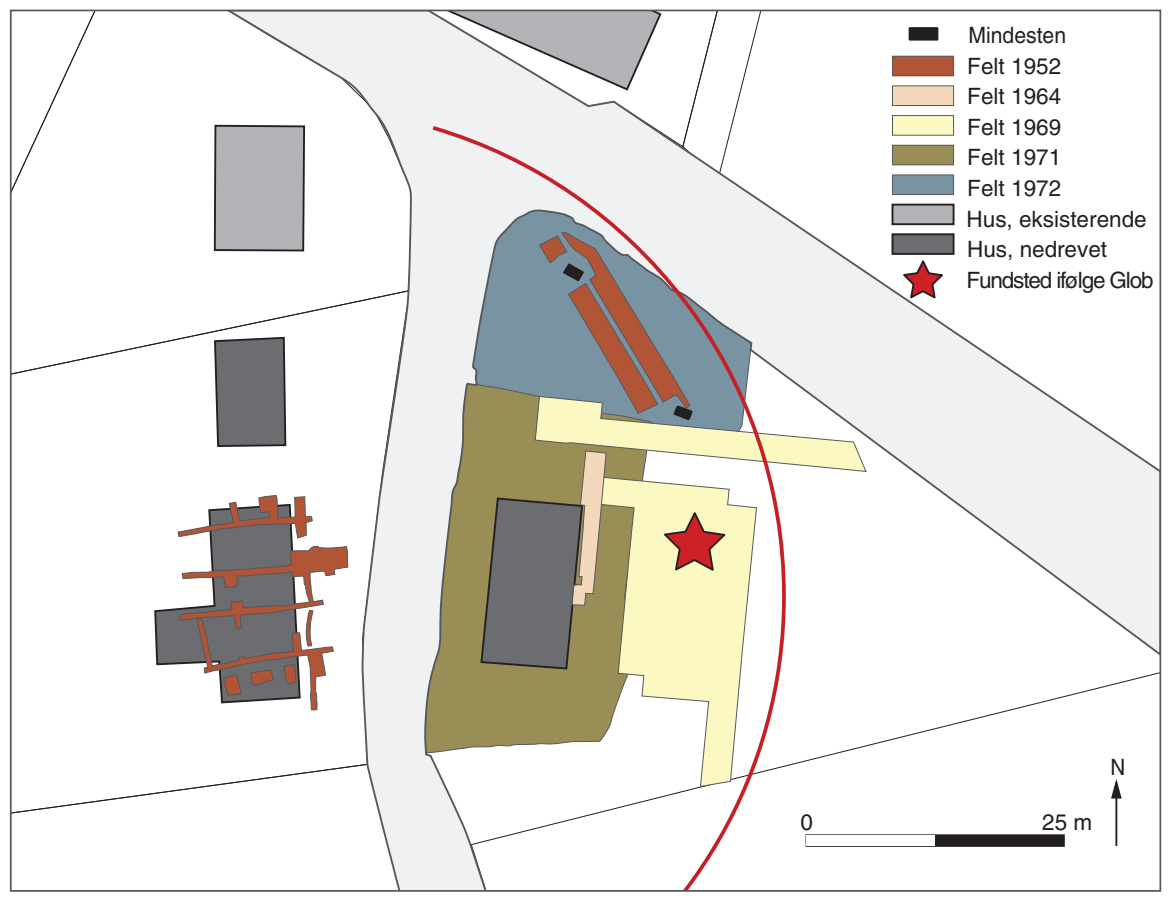

Fig. 12. Stjernen angiver området, hvor Glob mente at have påvist guldhornenes findested. Cirkelslaget angiver en afstand fra Lassens hus på 47 meter. - Rentegning: Carsten Meinertz Risager, Arkæologisk IT, Moesgaard.

The star marks the area where the golden horns was found according to Glob.

var med nød og næppe, han fandt midlerne til de nye, snoede guldhorn, der først blev færdige i 1979.

Med Iversens fund af indberetningen fra 1734 må Glob have indset, at afstanden mellem guldhornenes fundsteder ikke var 19 meter, men højst 7 meter, og at det med de mere sikre målangivelser ville være muligt at finde stedet, hvor hornene var nedlagt. ${ }^{11}$ I 1952 indså han dog nok, at han næppe ville finde den manglende spids af det sidste guldhorn og heller ikke noget gudehov. At undersøgelserne fortsatte, skal ses i lyset af museumsplanerne. I 1969 var det for at komme ud af den klemme, han og Hans Schack sad i, da planen om et museum i 1832-huset forliste, og i 1971-72 var det for at skabe interesse for nye museumsplaner, der altså også led skibbrud. 


\section{NOTER}

1. Iversen 1950.

2. Rafn 1855; Lauridsen 1908.

3. Lauridsen 1908, s. 1.

4. Rafn 1855, s. 352.

5. Lauridsen 1908, s. 2.

6. Vestkysten 19/6 1969.

7. Lauridsen 1908, s. $16 f$.

8. Vestkysten 6/5 1952.

9. Vestkysten 17/5 1952.

10. Vestkysten 24/1 1970.

11. Måleangivelserne i meter tager udgangspunkt i Lauridsens beregninger, hvorefter 1 skridt svarer til 1,88 meter. I andre sammenhænge angives 1 skridt dog til 5 fod svarende til 1,57 meter.

\section{LITTERATUR}

Brøndsted, Johannes 1954: Guldhornene. København.

Davidsen, H.C. 1921: Guldhornene fra Gallehus. Tønder.

Iversen, Peter Kr. 1950: Erik Lassens fund af det andet guldhorn 1734. Sønderjysk månedsskrift 1950, 26. årg., nr. 12, s. 187-191.

Lauridsen, P. 1908: Historiske og topografiske Oplysninger om Guldhornsfundene ved Gallehus. Aarbøger for nordisk Oldkyndighed og Historie 1908, s. 1-28.

Rafn, C.C. 1855: De tvende ved Gallehuus fundne Guldhorn, efter de ældre Beskrivelser. Annaler for nordisk Oldkyndighed og Historie 1855, s. 347-364.

Desuden: Museumssag nr. 142 oprettet af Forhistorisk Museum i 1951 og diverse avisudklip i Nationalmuseet. 


\section{Hunting for the find spots for the golden horns of Gallehus}

It is common knowledge that the golden horns were found at Gallehus in 1639 and 1734 and, consequently, so early that information on the find spots and finds circumstances is extremely sparse. In 1855, C.C. Rafn reached the conclusion that the horns were discovered in an undeveloped common area in the town (fig. 2), while in 1908, P. Lauridsen believed he had established the precise find spots, which were then marked with commemorative stones (figs. 3 and 4). With the discovery in 1951 of a report from 1734, it became clear that Lauridsen's locations were incorrect and that the two finds spots are unlikely to have been more than $7 \mathrm{~m}$ apart, i.e. significantly less than the distance he concluded (fig. 1). This prompted Professor P.V. Glob to launch an investigation of the area in 1952, aimed at finding possible evidence that could explain these depositions. Glob continued his investigations in 1964, 1969 and 1971-
72 (fig. 5). But he never managed to write a concluding report, and this article is an attempt to summarise his findings. The most important of these was the discovery of numerous pits, most of which were not very deep and had a very flat base. Many of them had apparently stood open for a shorter or longer period and they were therefore interpreted as clay pits (figs. 6-8). In 1969, some of these pits were found in an area corresponding to the find spot for one of the golden horns as specified in the 1734 source. Glob therefore believed he had found the actual find spot (figs. 10 and 12). The investigation in 1972 showed that these clay pits lay in the northeastern part of a larger more or less coherent complex of clay pits (fig. 7). Secure dating of these was not possible, but the fact that a house was built in 1832 over the southwesternmost corner of the complex testifies to a considerable age.

Sven Thorsen Nykøbing Falster 